\title{
Effect of Waterjet Machining Parameters on Cut Quality of Polymeric Composite Materials Based on Biological Reinforcement in Form of Cotton Post-harvest Line Residues
}

\author{
Miroslav Müller, Viktor Kolár, Petr Valášek \\ Faculty of Engineering, Czech University of Life Sciences Prague. Kamycka 129, 16500 Praha 6-Suchdol. Czech Re- \\ public.E-mail: muller@tf.czu.cz,vkolar@tf.czu.cz, valasekp@tf.czu.cz
}

\begin{abstract}
Composite materials are prospective materials. An intensive research on biological reinforced composite materials has taken place in recent years. The paper deals with utilization of just this biological filler in an area of the composite materials based on a synthetic laminating resin. A microparticle and short-fibre filler based on cotton postharvest line residues was used within the research. Many research studies devote to an evaluation of mechanical properties and an interaction of the filler and the matrix. Also a production of a final product is an integral part of the composite material development, namely in terms of a practical application. The research focused on an essential production part, namely machining by means of a water jet technology and an optimization of the cutting process based on an evaluation of a traverse speed and a cut quality. The research results proved that it was suitable to use the abrasive water jet technology for the cut uniformity (the kerf taper angle) and a deformation elimination of outlet part of the water jet from the composite material. In case of using the water jet technology without abrasive it is suitable to use lower values of the traverse speed, ca. $250 \mathrm{~mm} / \mathrm{min}$.
\end{abstract}

Keywords: composites, biological filler, prospective technology, water jet

\section{Introduction}

Composite materials need to be machined and divided. Conventional methods comprise common machining processes such as milling, drilling etc. However, these types of processes cause dangerous damages on the machined composite surface. A degradation and a delamination of a reinforcement/matrix belong among the most significant defects at the machining [1, 2, 3, 4]. The conventional machining methods represent another risk in terms of an operator risks. Micro and nanoparticles are released at the machining which can have a negative influence for the operator and for environment quality overall [3]. All above mentioned factors are undesirable for the operator of a production line and for a product user [5].

Various variants of cutting by means of the water jet technology (WJ) belong among prospective methods of the composite materials dividing $[6,7,8,9]$. The WJ technology principle consists in a creation of high water pressure, which goes through a nozzle of a small diameter, and the water jet creates high kinetic energy which enables to machine heterogeneous materials $[8,10,11,12]$. The WJ technology effect is increased by adding abrasive particles. Then it is the abrasive water jet technology (AWJ) [10]. A research by means of SEM analysis proved that AWJ technology can be effectively used for dividing and machining of composite materials $[2,4,11,12]$.

Biocomposites, eventually composites using a biological reinforcement, are trends of the composite materials production. Cotton has been the most extended textile fibre in the world at the present [13]. A by-product, i.e. waste in form of post-harvest residues, e.g. cotton shank and cotton plant roots, comes into being when harvesting cotton. A lignocellulose is a main component of these shanks. This cotton harvest waste is burned in most cases [14]. Ten millions tones of this waste on average have arisen each year in Europe and America and there is a great effort to increase a recycling rate of the cotton postharvest line waste $[15,16]$. It is possible to add this waste, except for the energy use, in a form of the filler into the composite materials. The cellulose based filler composites are used thanks to their low production costs, and low volume mass above all [17]. A reason for utilization of these fillers is an improvement of mechanical properties above all, e.g. a tensile strength, a flexural strength or a material fatigue (namely at fibres) $[15,18,19]$. The cellulose based particle filler is a secondary product of postharvest processing. When using the filler in the form of particles it cannot be expected the improvement of mechanical properties. Often it is the other way around.

This paper deals with the utilization of these fillers in the area of the composite materials based on the synthetic laminating resin and the biological filler. Cotton microparticle and short-fibre post-harvest line residue filler was used within the research. These composite materials are determined as designed surface cover part above all, e.g. in furniture industry. The research focused on the essential production part, namely on the machining by means of the water jet technology and on the cutting process optimization based on the evaluation of the traverse speed and the cut quality. Results of mechanical tests of the composite materials and the composite adhesive bonded layer with the cotton post-harvest line residues filler certified the efficiency of these materials for the practical application [17].

\section{Material and Methods}

Cotton post-harvest line residues come from the cotton machine harvest. An inlet raw material is visible in fig. 1 A. A surface structure of the inlet raw material is obvious from SEM image (fig. 1 B, C). A predominant portion of shanks was in the inlet raw material for the production of cotton based filler (FC). This inlet raw material based on the cotton post-harvest waste was dried for 24 
hours at the temperature $105 \pm 5{ }^{\circ} \mathrm{C}$ after which a multistage grinding in an industrial grinder and a sieve sorting followed. Filler characterized in tab. 1 and in fig. 2 was used within the research. The particle size was determined by means of an image analysis with use of Gwyddion program and electronic microscopy images
(SEM). It is obvious from a comparison of a length and a diameter of the tested fibre filler FC500 that it is the shortfibre filler whose ratio length/diameter was 11.2, i.e. considerably smaller than 100. Particle and short-fibre fillers behave in the composite systems as anisotropic discontinuous reinforcing phase $[17,20]$.

Tab. 1 Dimensional results characterizing cotton filler $(F C)$ from electron microscopy images (SEM) by means of Gwyddion program

\begin{tabular}{|c|c|c|c|c|}
\hline Indication & Filler type & Arithmetic mean $(\mu \mathrm{m})$ & Mode $(\mu \mathrm{m})$ & Median $(\mu \mathrm{m})$ \\
\hline FC 30 & Particle & $31.27 \pm 21.87$ & 21 & 25 \\
\hline FC 150 & Particle & $152.69 \pm 108.08$ & 101 & 120 \\
\hline FC 500 & Short fibres & $512.30 \pm 367.77$ & 712 & 454 \\
\hline
\end{tabular}
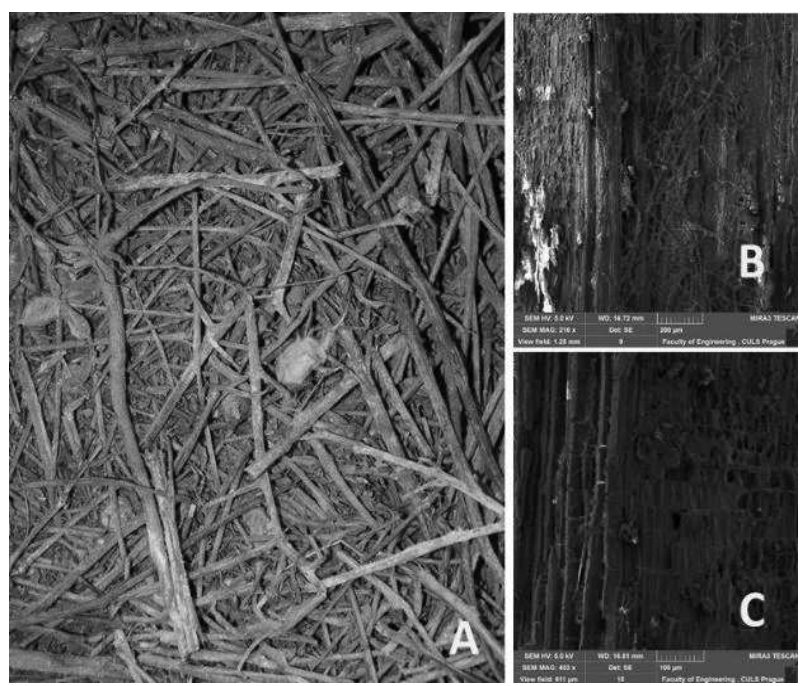

Fig. 1 Inlet raw material based on cotton post-harvest line residues before treating process to composite material filler: A: general view on inlet raw material, $B$ : $S E M$ images of inlet raw material surface (MAG $216 x$ ), $C$ : SEM images of inlet raw material surface (MAG 453 $x)$
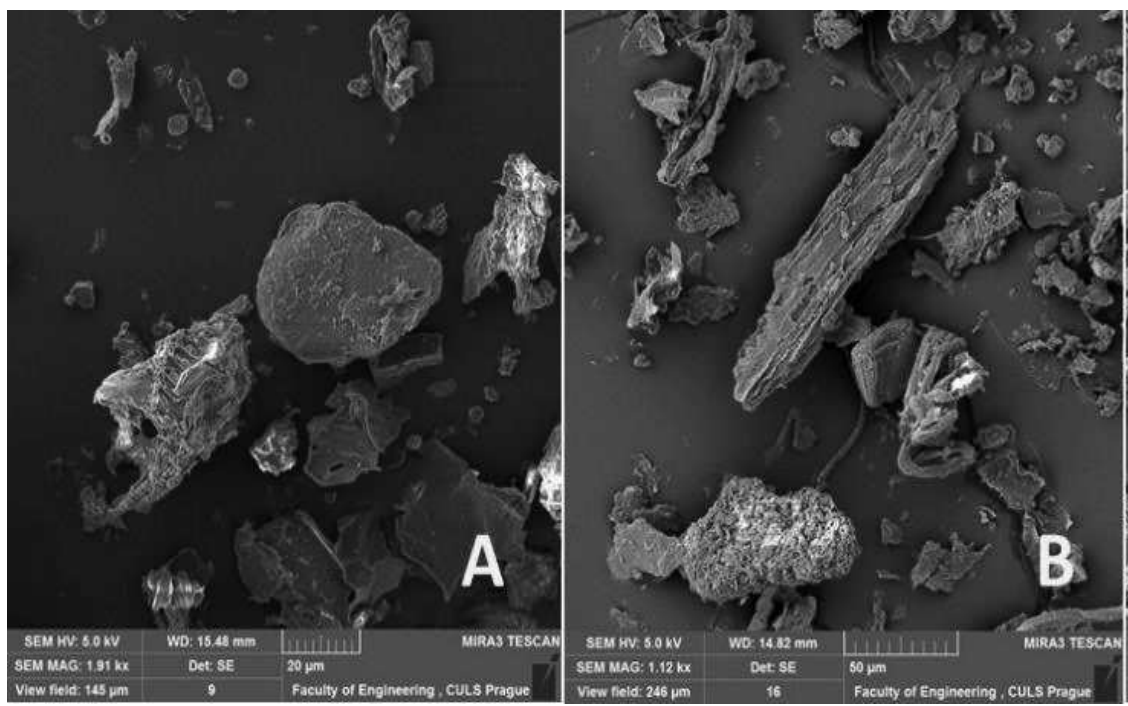

A preparation of composite boards was performed by means of a vacuum infusion at which a vacuum is used to guide a resin through the filler FC 30, FC 150 and FC 500. The structural epoxy resin LH 288 with the hardener $\mathrm{H}$ 282 of Havel Composites Company (MHC) was the matrix. A minimum porosity and a perfect saturation of the resin with the filler are advantages of the vacuum infusion technology. A vacuum pump was used for the vacuum process which drains air from closed mould and creates the vacuum (fig. 3 A). The resin is sucked from the tank into the product mould under the vacuum 0.8 to 1 bar. The vacuum infusion uses the vacuum for a distribution of the resin in laid layers of the reinforcement. The filler FC is laid into the mould cavity of dimensions $200 \times 300 \times 4$ $\mathrm{mm}$. The production process by means of the vacuum infusion consists of following technological operations mould preparation, preparation of filler FC, gelcoat, adding auxiliary materials into mould, installation of vacuum foil, installation of vacuum, check of vacuum and production itself. The resin (matrix) is sucked by means of small tube system and by means of a distribution medium. The composite board was prepared with 40 wt. $\%$ of the filler FC of dimensions $220 \times 130 \times 4 \mathrm{~mm}$. Variants of the composite board production are presented in tab. 2 .

Fig. 2 Cotton post-harvest line residue based filler for composite materials after treatment (FC): A: FC 30 (MAG 1.91 $k x$ ), B: FC 150 (MAG $1.12 \mathrm{kx}$ ), C: FC 500 (MAG $139 x$ ) 
Tab. 2 Characteristics of tested polymeric composite materials with biological reinforcement based on cotton post-harvest line residues

\begin{tabular}{|c|c|}
\hline Composite material & Characteristics \\
\hline PCFC 30 & $\begin{array}{c}\text { Polymeric particle composite based on matrix Havel Composite and cotton filler of } \\
\text { particle size } 30 \mu \mathrm{m} .\end{array}$ \\
\hline PCFC 150 & $\begin{array}{l}\text { Polymeric particle composite based on matrix Havel Composite and cotton filler of } \\
\text { particle size } 150 \mu \mathrm{m}\end{array}$ \\
\hline PCFC 500 & $\begin{array}{l}\text { Polymeric particle composite based on matrix Havel Composite and cotton filler of } \\
\text { particle size } 500 \mu \mathrm{m} .\end{array}$ \\
\hline
\end{tabular}

Technologies AWJ (abrasive water jet) and WJ (water jet) of polymeric composite materials with different biological reinforcement were used for the research dealing with the cutting process optimization of polymeric composite materials with the biological reinforcement based on the cotton post-harvest line residues (fig. $3 \mathrm{~B}$ ). The quality of the cutting gap surface evaluated by the optical analysis was used for the optimization of the cutting process by the water jet technology of composite materials (fig. $3 \mathrm{C}$ ).

Tested composite materials based on the biological reinforcement were cut by CNC cutting machine AWJ CT 0806 with different traverse speeds of cutting head -50 , 250, 750 and $1000 \mathrm{~mm} / \mathrm{min}$ in the cut length $60 \mathrm{~mm}$. Other parameters, i.e. setting of $\mathrm{CNC}$ cutting machine AWJ CT 0806, were constant at the tests: the working pressure was $380 \mathrm{MPa}$, a distance of the nozzle above the cut material was $3 \mathrm{~mm}$, the diameter of the nozzle was 0.8 $\mathrm{mm}$ and an angle of the nozzle tilt to the composite material was $90^{\circ}$.
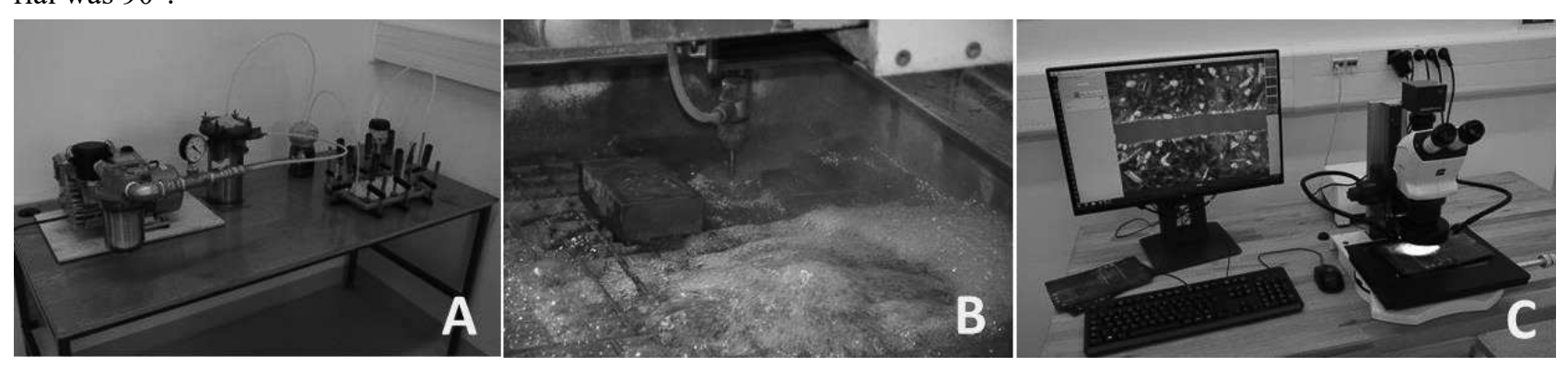

Fig. 3 Testing process: A: production of composite material by vacuum infusion, B: cutting of composite material by CNC cutting machine AWJ CT 0806 with different traverse speed of cutting head, C: evaluation of cut by means of optical analysis.

\section{Results and Discussion}

Results of the research on machining of polymeric material reinforced with cotton post-harvest line residues (FC), i.e. determining of the kerf width inlet and outlet of the water jet, are visible in fig. 4 (PCFC30), fig. 6 (PCFC150) and fig. 8 (PCFC500). Frequency histograms of filler FC particular sizes are visible from fig. 4 (PCFC30), fig. 6 (PCFC150) and fig. 9 (PCFC500). The cutting zone of composite materials showed huge differences between WJ and AWJ which is visible from fig. 4, 6 and 8 . The difference between AWJ technology using a water stream with abrasive particles and WJ technology, i.e. the water stream, is obvious from the results. The significant difference between the kerf width inlet and outlet at the WJ technology at the traverse speed 750 and 1000 $\mathrm{mm} / \mathrm{min}$ is evident from the results. It is obvious in terms of the statistical comparison of the traverse speeds 50 ,
Two variants of the water jet cutting technology were used: AWJ abrasive water jet technology with abrasive grains of Australian garnet MESH 80 (mechanical dosing equipment Bimba Flat $90.6 \pm 1.15 \mathrm{~g} / \mathrm{min}$ ), WJ water jet technology without abrasive particles.

Measuring of cutting gaps was performed inlet and outlet of the water jet. Values of the cutting gap were measured in the stereoscopic microscope Zeiss Stemi 508 with cam Axiocam and evaluated by software (fig. $3 \mathrm{C}$ ). The measurement was performed $10 \mathrm{~mm}$ from the inlet of the water jet into the composite material and was finished $10 \mathrm{~mm}$ before the end of the cut. A reason was to eliminate results distorted by the water jet shot into the composite material. The kerf taper angle of the composite material cut was evaluated according to the equation 1 [11, 21]. The thickness of the tested material $t$ was constant for all three tested composite boards.

$$
T=\arctan \left(\frac{\text { Kerf } \text { width }_{\text {Inlet }}-\text { Kerf }_{\text {width }} \text { Outlet }}{2 . t}\right)
$$


WJ technology and higher traverse speeds (namely 1000 $\mathrm{mm} / \mathrm{min}$ ) (fig. 5, 7 and 9). Also in inlet side in some cases, fig. 5 is an example. Hejjaji et al. proved in their research an essence of the traverse speed influence at the car-

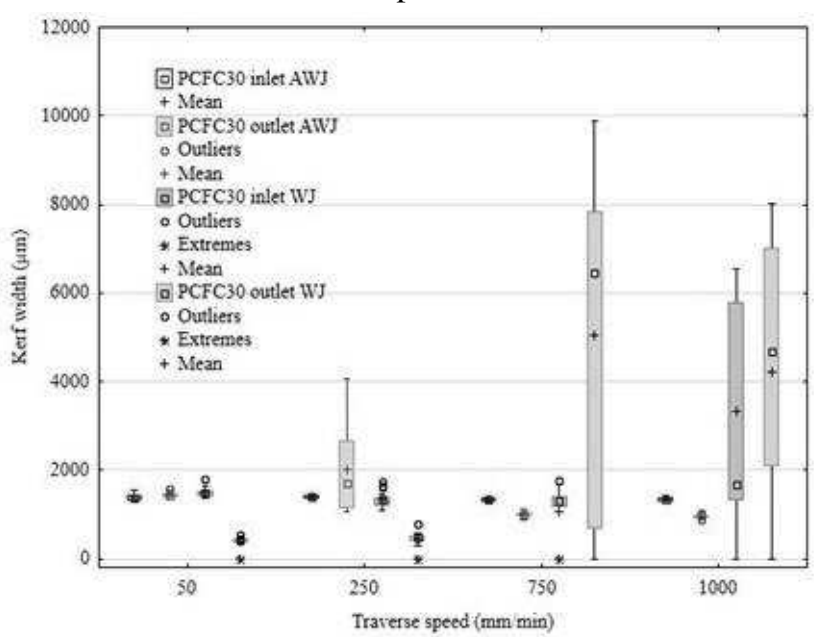

bon/epoxy composite material machining [22]. The research results also clearly proved an essence of the traverse speed at both AWJ and WJ, i.e. the essence of the optimization and the influence on the cut quality.

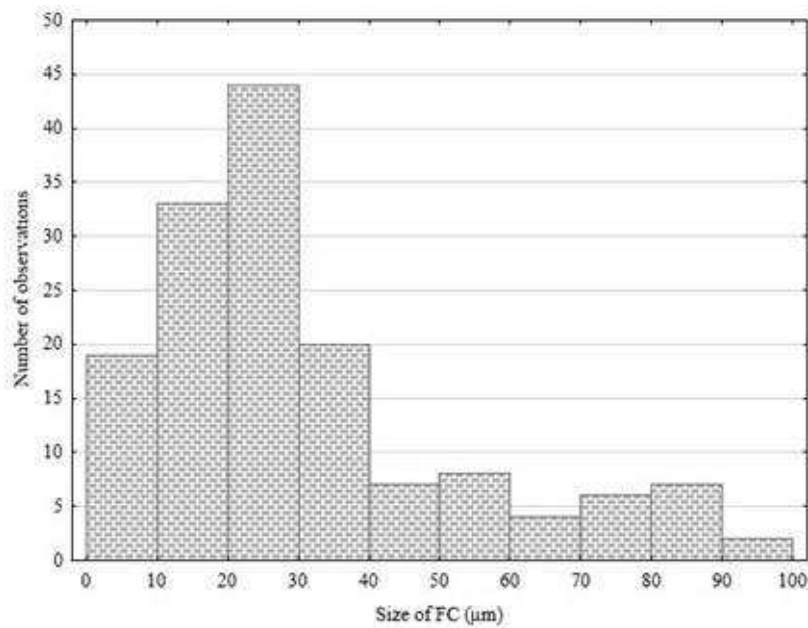

Fig. 4 Kerf width of cut by WJ and AWJ technology of polymeric composite PCFC30 - cotton particle filler of size 30 $\mu \mathrm{m}$ (left), Histogram of cotton based filler indicated as FC 30 (right)
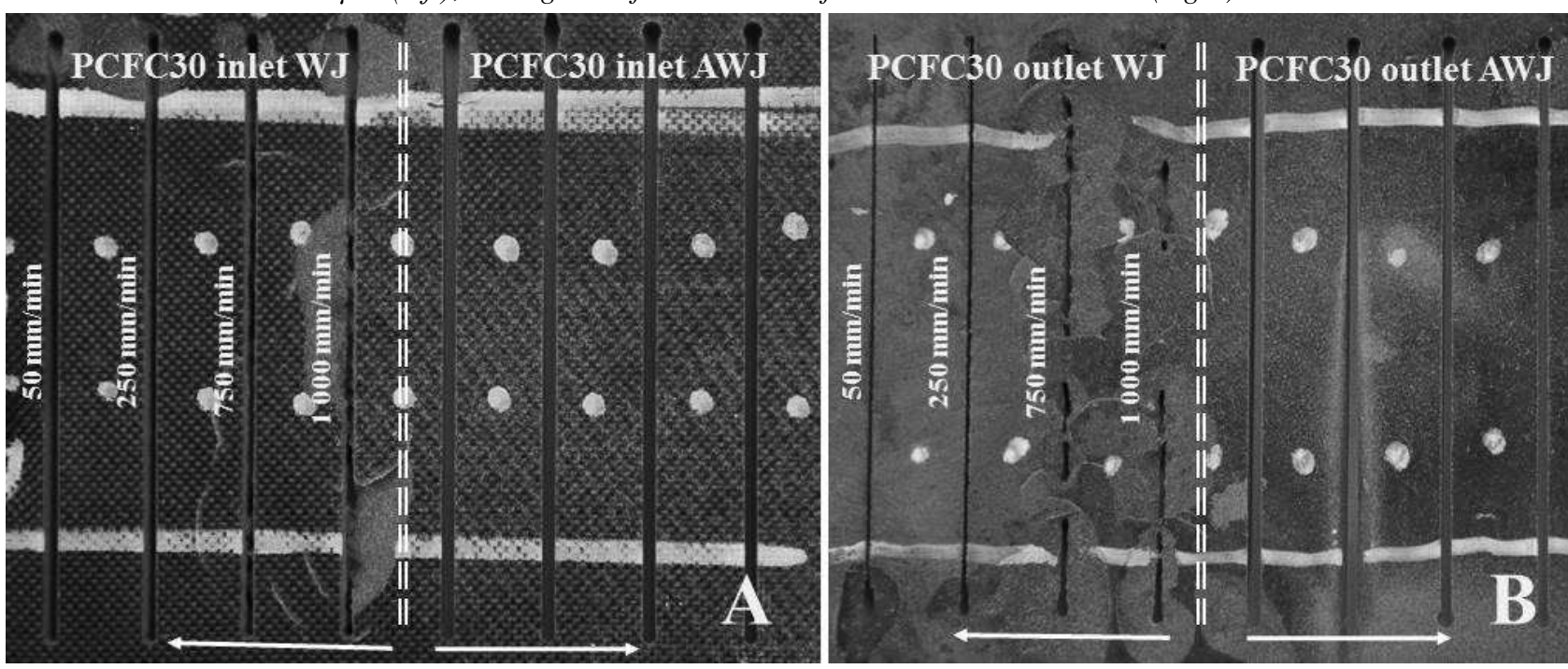

Fig. 5 Comparison of particular cuts through composite material indicated as PCFC30: A: inlet of PCFC30, B: outlet of PCFC3O
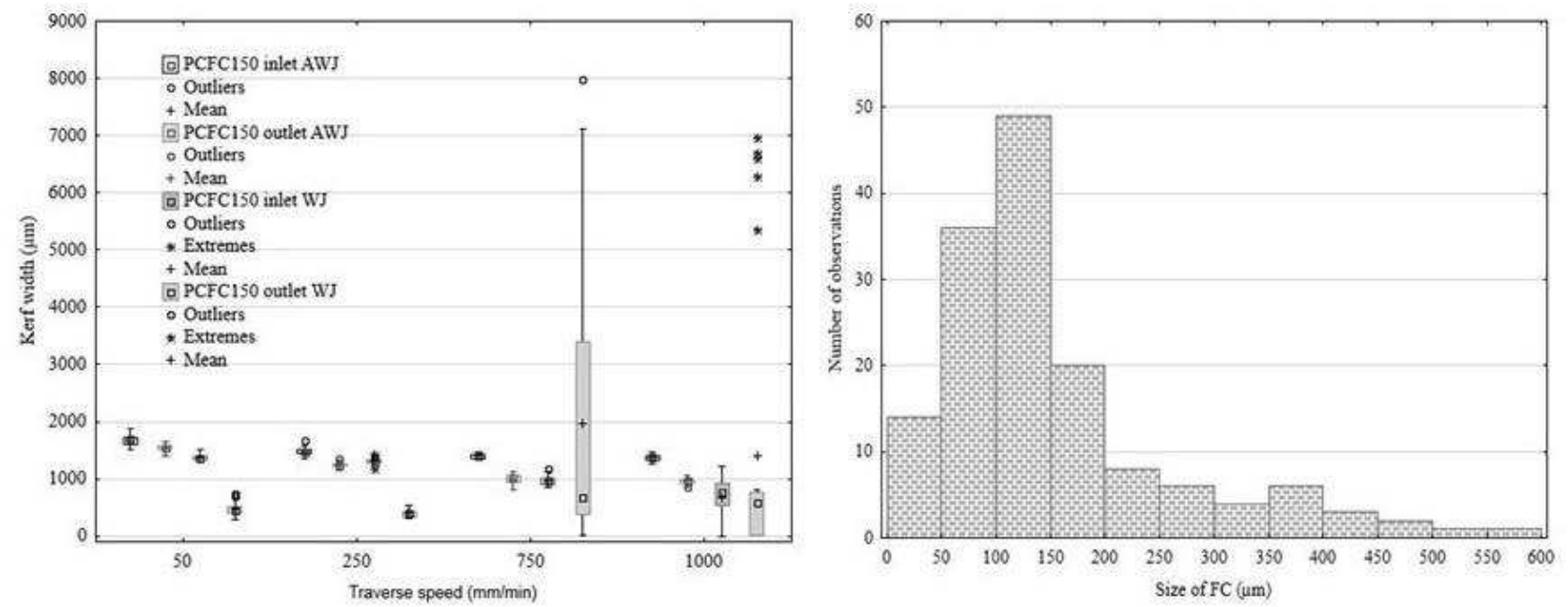

Fig. 6 Kerf width of cut by WJ and AWJ technology of polymeric composite PCFC150 - cotton particle filler of size 150 um (left), Histogram of cotton based filler indicated as FC 150 (right) 

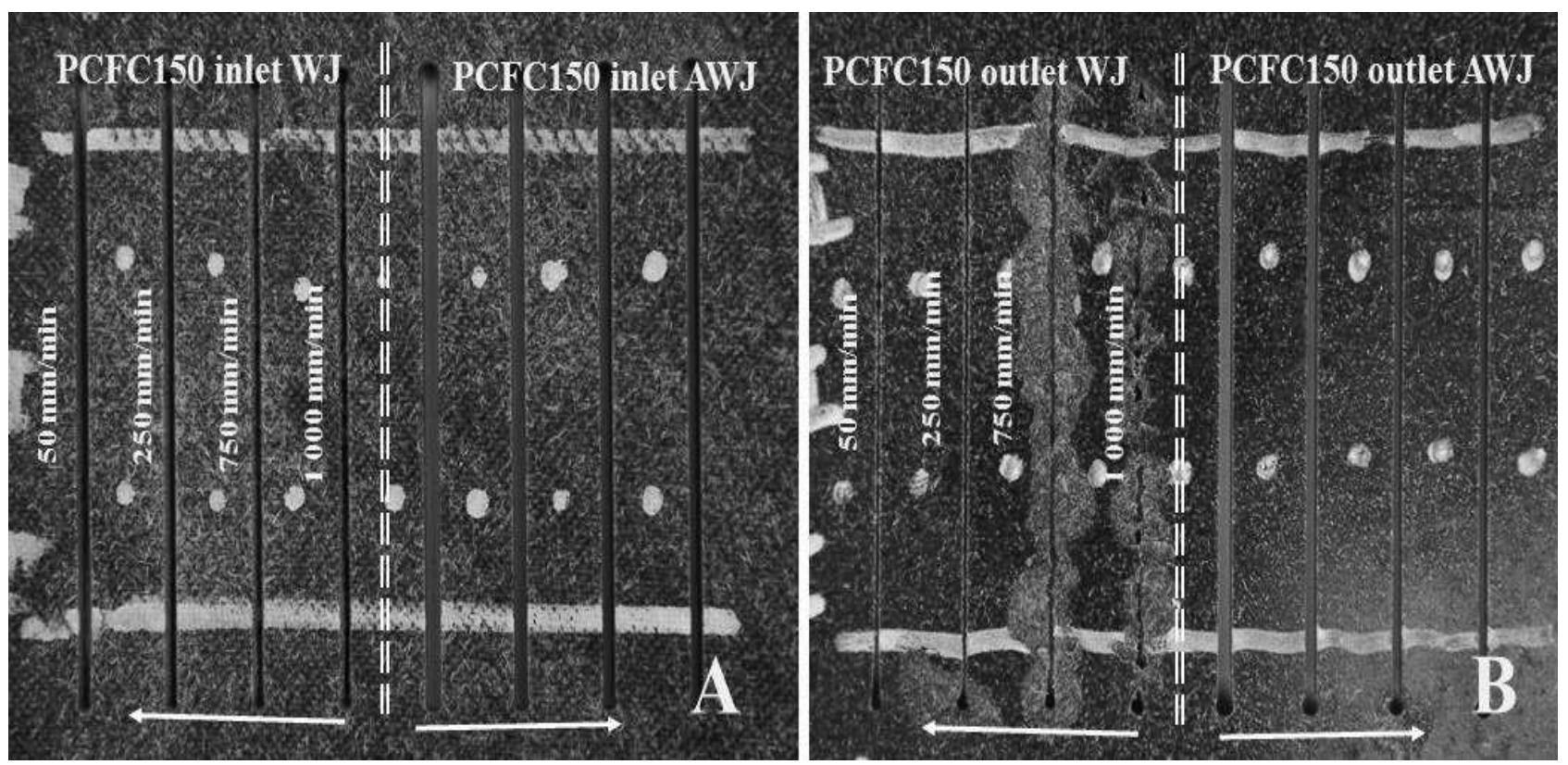

Fig. 7 Comparison of particular cuts through composite material indicated as PCFC150: A: inlet of PCFC150, B: outlet of PCFC150
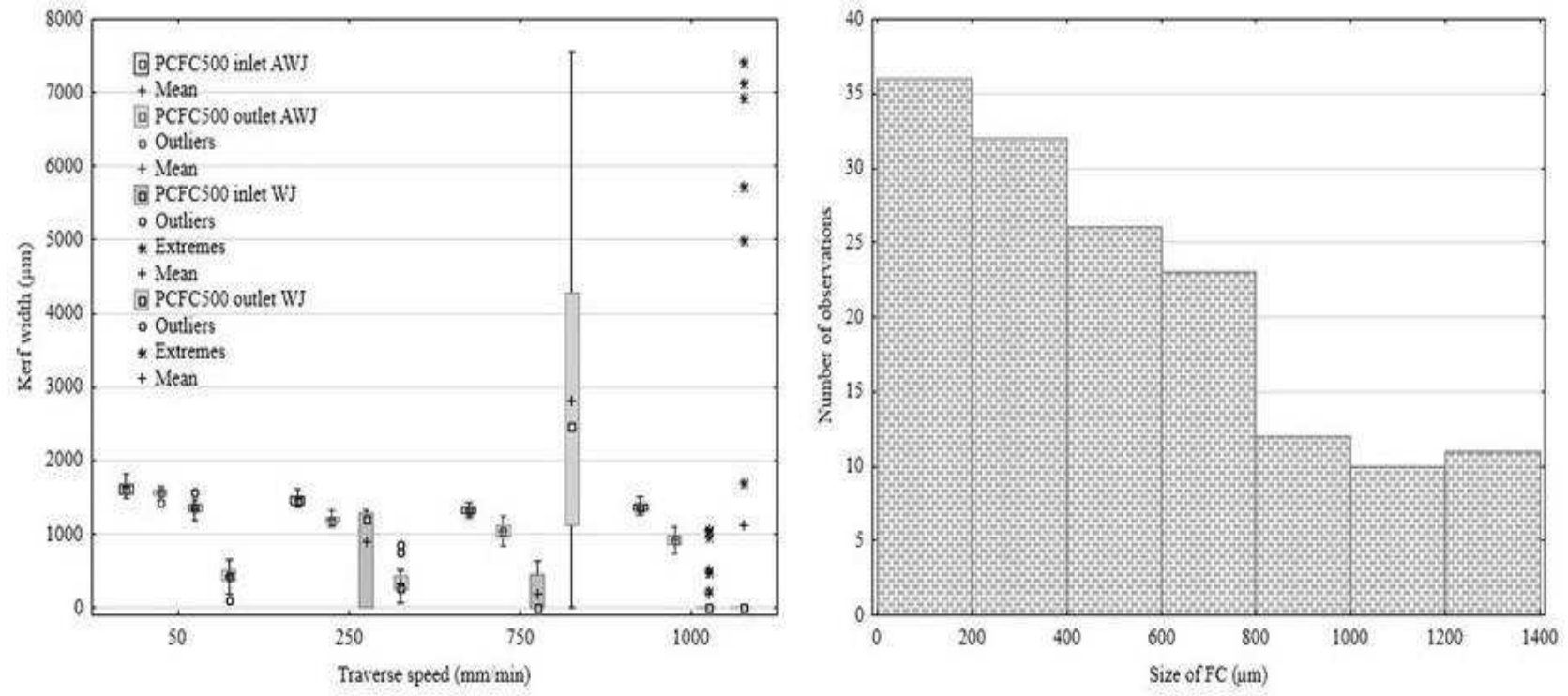

Fig. 8 Kerf width of cut by WJ and AWJ technology of polymeric composite PCFC500 - cotton short-fibre filler of length $500 \mu \mathrm{m}$ (left), Histogram of cotton based filler indicated as FC 500 (right)

Results of the taper angle measuring, which is essential for the cut quality evaluation, are obvious from tab. 3 . The taper angle is more even at the traverse speed 50 $\mathrm{mm} / \mathrm{min}$ at the use of AWJ technology than at WJ technology. The gap thickness inlet and outlet is similar. The cut is almost vertical. The kerf width outlet is smaller than inlet. It is obvious that the jet is losing its kinetic energy, i.e. it cannot additionally remove the material in the bottom part of the cut which leads to a narrow kerf outlet [23]. This conclusion is evident in fig. 5, 7 and 9. A resultant increase of the taper angle, which is obvious namely at WJ technology, is connected with it. Wang states that the taper angle is slightly increasing with increasing traverse speed [23]. This conclusion was certified at PCFC150 and PCFC500. It is caused above all because the motion of the CNC machine cutting head is faster at higher traverse speeds at constant dosage of abrasive and the water jet with abrasive is losing the kinetic energy. This conclusion was confirmed by Jun Wang [23]. It was ambiguous at the composite material PCFC30, namely at the traverse speed $250 \mathrm{~mm} / \mathrm{min}$. The cut visualisation is evident from fig. 5, 7 and 9. The research certified conclusions of various researches that first-quality cuts of polymeric composite materials can be effectively prepared by AWJ technology $[4,11,23]$. 

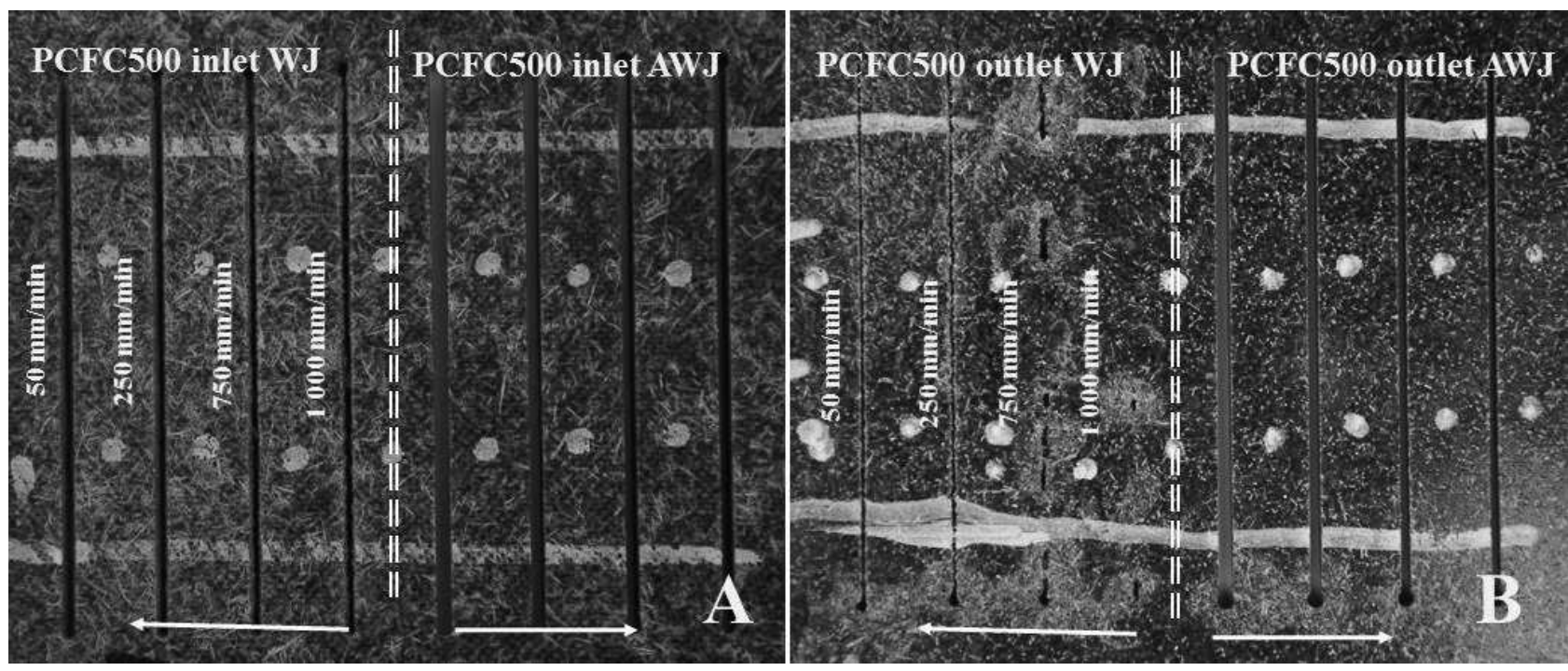

Fig. 9 Comparison of particular cuts through composite material indicated as PCFC500: A: inlet of PCFC500, B: outlet of PCFC500

It is necessary to choose optimal traverse speed, namely at WJ technology. It comes to two states at unsuitable / higher traverse speeds (750 and $1000 \mathrm{~mm} / \mathrm{min}$ ), namely to an incomplete cut of the material or to a destruction of the cut bottom part. The taper angle is then negative which is visible from tab. 3 . The negative taper angle of PCFC composite material cut presents a significant and irregular deformation on the water jet outlet from the material which is evident from fig. 5, 7 and 9 B. The research results certified conclusions of authors who dealt with the optimization of the machining process where it is necessary to take into regard specific requirements of different materials beginning from sandstone, claimed alloy, steel to sintered metal etc. [4, 7, 9, 21, 24, 25, 26, 27, 28].

Tab. 3 Taper angle of cut of composite materials based on biological reinforcement from microparticles and short nonoriented cotton fibres

\begin{tabular}{|c|c|c|c|c|c|}
\hline \multicolumn{2}{|c|}{ Traverse speed (mm/min) } & 50 & 250 & 750 & 1000 \\
\hline \multirow{3}{*}{ PCFC30 } & AWJ & $0^{\circ} 20^{\prime}$ & $4^{\circ} 18^{\prime}$ & $2^{\circ} 27^{\prime}$ & $2^{\circ} 38^{\prime}$ \\
\cline { 2 - 6 } & WJ & $7^{\circ} 51^{\prime}$ & $6^{\circ} 25^{\prime}$ & $-26^{\circ} 31^{\prime}$ & $-6^{\circ} 14^{\prime}$ \\
\hline \multirow{3}{*}{ PCFC150 } & AWJ & $0^{\circ} 56^{\prime}$ & $1^{\circ} 40^{\prime}$ & $2^{\circ} 47^{\prime}$ & $2^{\circ} 59^{\prime}$ \\
\cline { 2 - 6 } & WJ & $6^{\circ} 23^{\prime}$ & $6^{\circ} 29^{\prime}$ & $-7^{\circ} 7^{\prime}$ & $-5^{\circ} 10^{\prime}$ \\
\hline \multirow{2}{*}{ PCFC500 } & AWJ & $0^{\circ} 28^{\prime}$ & $1^{\circ} 52^{\prime}$ & $2^{\circ} 7^{\prime}$ & $3^{\circ} 13^{\prime}$ \\
\cline { 2 - 6 } & WJ & $6^{\circ} 38^{\prime}$ & $4^{\circ} 8^{\prime}$ & $-18^{\circ} 12^{\prime}$ & $-6^{\circ} 47^{\prime}$ \\
\hline
\end{tabular}

\section{Conclusions}

The experiment results focused on the machining of polymeric composite materials with the biological reinforcement - cotton microparticle and short-fibre post-harvest line residues filler - by the water jet and the abrasive water jet technologies at different traverse speeds. The research results proved:

- The essence of the traverse speed at both AWJ and WJ, i.e. the essence of its optimization and the influence on the cut quality. This conclusion is underlaid by the results presented in graphs and figures from which the cut is visible.

- Low effectivity of the composite material machining by the water jet technology without abrasive. The negative aspect of this technology is an unevenness of the cutting gap, i.e. a significant difference between the kerf width inlet and outlet at WJ technology at the traverse speeds 750 and $1000 \mathrm{~mm} / \mathrm{min}$. The significant destruction on the bottom side of the cut or the uncut of the tested material occurred at higher traverse speeds (from $750 \mathrm{~mm} / \mathrm{min}$ ). At PCFC 30, the destruction occurred also on upper side of the cut, i.e. inlet the water jet without abrasive into the composite material, at the traverse speed 1000 $\mathrm{mm} / \mathrm{min}$. This negative aspect occurred only at the composite material with the smallest particle filler of dimensions ca. $30 \mu \mathrm{m}$. A smaller cutting gap towards the abrasive water jet technology with abrasive garnet MESH 80 is the positive factor.

- Adding abrasive into the water jet, i.e. the use of abrasive water jet technology, had the positive effect on the cut quality. The taper angle was more even at all tested traverse speeds at using abrasive water jet technology. It ranged in the 
interval $0^{\circ} 20^{\prime}$ to $4^{\circ} 18^{\prime}$. The significant influence on the cutting gap did not manifest at tested composite materials. Faster motion of the cutting head of CNC machine occurred at higher traverse speeds at the constant dosing of abrasive. The water jet with abrasive lost its kinetic energy.

\section{Acknowledgements}

This paper has been made with the assistance of the grant IGA TF CZU (Research on composite layer interactions at hybrid adhesive bonds, Czech University of Life Sciences Prague no. 2019:31140/1312/313108.

\section{References}

[1] HERZOG, D., JAESCHKE, P., MEIER, O., HAFERKAMP, H. (2008). Investigations on the thermal effect caused by laser cutting with respect to static strength of CFRP. In: International Journal of Machine Tools and Manufacture. Vol. 48, No. 12-13, pp. 1464-1473.

[2] HEJJAJI, A., SINGH, D., KUBHER, S., KALYANASUNDARAM, D., GURURAJA, S. (2016). Machining damage in FRPs: Laser versus conventional drilling. In: Composites Part A: Applied Science and Manufacturing. Vol. 82, pp. 4252.

[3] XU, W., ZHANG, L. (2018). Tool wear and its effect on the surface integrity in the machining of fibre-reinforced polymer composites. In: Composite Structures. Vol. 188, pp 257-265.

[4] MULlER, M., D'ARMATO, R., RUDAWSKA A. (2017). Machining of polymeric composite by means of abrasive water-jet technology. In: 16th International Scientific Conference Engineering for Rural Development. Jelgava, Latvia University of Agriculture, pp. 121- 127.

[5] MAYUET, P.F., GIROT, F., LAMÍKIZ, A., FERMÁNDEZ-VIDAL, S.R., SALGUERO, J., MARCOS, M. (2015). SOM/SEM based Characterization of Internal Delaminations of CFRP Samples Machined by AWJM. In: Procedia Engineering, Vol. 132, pp. 693-700.

[6] CÁRACH, J., HLOCH, S., PETRŮ, J., MÜLLER, M., HROMASOVÁ, M., NAG, A., ČUHA, D., HLAVÁČEK, P., HATALA, M., KRATOCHVÍL, J., RUGGIERO, A. (2019). Evaluation of physical phenomena and surface integrity during hydroabrasive disintegration of the rotating workpiece with feedback loop control. In: MEASUREMENT. Vol. 134, pp. 586-594.

[7] RAJ, P., HLOCH, S., TRIPATHI, R., SRIVASTAVA, M., NAG, A., KLICHOVÁ, D., KLICH, J., HROMASOVÁ, M., MÜLLER, M., LINDA, M., CHATTOPADHYAYA, S., ADAMCIK, P. (2019). Investigation of sandstone erosion by continuous and pulsed water jets. In: Journal of Manufacturing Processes. Vol 42, pp. 121-130.

[8] MÜlleR, M., VALÁŠEK, P., LINDA, M., KOLÁř, V. (2018). Research on water jet cutting of composites based on epoxy/microparticles from coconut shell. In: MATEC WEB of Conference 3rd Innovative Technologies in Engineering Production, Bojnice, SK. Bojnice Slovakia: EDP Sciences, $9 \mathrm{p}$.

[9] SRIVASTAVA, M., HLOCH, S., MÜLlER, M., HROMASOVÁ, M., CAIS, J., CHATTOPADHYAYA, S., DIXIT, A., KLICH, J. (2019). Effect of Frequency Change During Pulsed Waterjet Interaction with Stainless Steel. In: Advances in manufacturing engineering and materials, ICMEM 18.06.2018, Novy Smokovec, SLOVAKIA. BERLIN, GERMANY: SPRINGER-VERLAG BERLIN. pp. 85-96.

[10] WANG, J., GUO, D.M. (2002). A predictive depth of penetration model for abrasive waterjet cutting of polymer matrix composites. In: Journal of Materials Processing Technology, Vol. 121, pp. 390394.

[11] MÜlleR, M., VALÁŠEK, P., KOLÁŘ, V. (2018). Research on application of technology using water jet on machining of polymeric composite biological-reinforced materials. In: Manufacturing Technology. Vol. 18, No. 4, pp. 630-634.

[12] GNANAVELBABU, A., SARAVANAN, P., RAJKUMAR, K., KARTIHEYAN, S., BASKARAN, R. (2018). Effect of Abrasive Waterjet Machining Parameters on Hybrid AA6061-B4C- CNT Composites. In: Materialstoday Proceedings. Vol. 5, No. 5, pp. 1343813450 .

[13] BAJPAI, S.K., MARY, G., CHAND. N. (2015). The use of cotton fibers as reinforcements in composites. In: Biofiber Reinforcements in Composite Materials. pp. 320-341.

[14] HOU, X., SUN, F., YAN, D., XU, H., DONG, Z., LI, Q., YANG, Y., (2014). Preparation of lightweight polypropylene composites reinforced by cotton stalk fibers from combined steam flashexplosion and alkaline treatment. In: Journal of Cleaner Production. Vol. 83, pp. 454-462.

[15] WU, H., LIANG, X., HUANG, L., XIE, Y., TAN, S., CAI, X. (2016). The utilization of cotton stalk bark to reinforce the mechanical and thermal properties of bio-flour plastic composites. In: Construction and Building Materials. Vol. 118, pp. 337-343.

[16] BARBERO-BARRERA, M. del M., POMBO, O., NAVACERRADA, M de los A. (2016). Textile fibre waste bindered with natural hydraulic lime. 
In: Composites Part B: Engineering. Vol. 94, pp. 26-33.

[17] MULLER, M., VALAŠEK, P., KOLǍ̌, V., SLEGER, V., GURDIL, G.A.K., HROMASOVÁ. M., HLOCH, S., MORAVEC, J., PEXA, M. (2019). Material Utilization of Cotton Post-Harvest Line Residues in Polymeric Composites. In: Polymers, vol. 11, no. 7.

[18] YAN, L., KASAL, B., HUANG, L. (2016). A review of recent research on the use of cellulosic fibres, their fibre fabric reinforced cementitious, geopolymer and polymer composites in civil engineering. In: Composites Part B Engineering. Vol. 92, pp. 94-132.

[19] PETRUCCI, R., NISINI, E., PUGLIA, D., SARASINI, F., RALLINI, M., SANTULLI, C., MINAK, G., KENNY, J.M. (2015). Tensile and fatigue characterisation of textile cotton waste/polypropylene laminates. In: Composites Part B Engineering, Vol. 81, pp. 84-90.

[20] DEBNATH, S., RANADE, R., WUNDER, S.L., McCOOL, J. BOBERICK, K., BARAN, G. (2004). Interface effects on mechanical properties of particle-reinforced composites. In: Dental Materials. Vol. 20, pp. 677-686.

[21] ALBERDI, A., SUAREZ, A., ARTAZA, T., ESCOBAR-PALAFOX, G. A., RIDGWAY, K. (2013). Composite Cutting with Abrasive Water Jet. In: Procedia Engineering. Vol. 63, pp. 421 429.

[22] HEJJAJI, A., ZITOUNE, R., CROUZEIX, L., LE ROUX, S., COLLOMBERT, F. (2017). Surface and machining induced damage characterization of abrasive water jet milled carbon/epoxy composite specimens and their impact on tensile behavior. In: Wear, Vol. 376-377, pp. 1356-1364.

[23] WANG J. (1999). Abrasive water jet machining of polymer matrix composites-cutting performance, erosive process and predictive models. In: International Journal of Advanced Manufacturing Technology. Vol. 15, pp. 757-68.

[24] NAPRSTKOVA, N., KUSMIERCZAK, S. (2016). Analysis of Decrease Machinability Possible Causes for Claimed Alloy. In: Advances in Science and Technology-Researche Journal. Vol. 10, No. 31, pp. 94-101.

[25] NOVAK, M., NAPRSTKOVA, N. (2014). The influence of cutting conditions on surface roughness during steel X38CrMoV5 grinding. In: Key Engineering Materials. Vol. 581, pp. 247-254.

[26] MULLER, M., VALAŠEK, P. (2017). Research on aluminium alloy $\mathrm{AlCu} 4 \mathrm{Mg}$ surface machined by abrasive water jet. In: Manufacturing technology, Vol. 17, No. 6, pp. 925-930.

[27] NOVOTNÝ, J., LYSONKOVA, I., MICHNA, S., NÁPRSTKOVA, N. (2017). Research of Application Possibilities of Selected Mechanically Alloyed Metal Powders. In: Manufacturing technology, Vol. 17, No. 5, pp. 811-815.

[28] SHANMUGAM, D.K., NGUYEN, T., WANG, J. (2008). A study of delamination on graphite/epoxy composites in abrasive waterjet machining. In: Composites: Part A, Vol. 39, pp. 923-929. 